\title{
Oncolytic virotherapy including Rigvir and standard therapies in malignant melanoma [Corrigendum]
}

\author{
Babiker HM, Riaz IB, Husnain M, Borad MJ. Oncolytic \\ Virother. 2017;6:11-18.
}

On page 16, left column, line 19 from the bottom, our publication indicates: "However, the data should be interpreted with caution, given the retrospective nature of the study, lack of control arm or randomization and other biases inherent with studies that are not prospective in nature". However, the trial did have 52 malignant melanoma patients (post-surgical resection stages IB, IIA, IIB, and IIC) who did receive Rigvir, and 27 patients who were observed and treated per the standard guidelines (control group). Hence, there was a control group as in indicated in Figure 1 in the Doniņa et al paper. ${ }^{1}$

On page 16, left column, line 16 from the bottom, our publication indicates: "From a safety perspective, it was reported that there were no severe treatment-related toxicities. However, detailed data supporting this were not provided in the study publication, making it difficult to interpret objectively". The authors would like to indicate regarding publication by Doniņa et al, ${ }^{1}$ Melanoma Research 2015 , that Table 4 detailed the serum chemistry parameters of the patients. While no details of clinical adverse events, serious adverse events, or treatment related adverse events were highlighted, the authors do indicate on the paper that "In this retrospective study, however, that there was no record of any untoward side effect from Rigvir treatment or its discontinuation" (page 423 line 7 from the bottom, Doniņa et $\mathrm{al}^{1}$ ).

\section{Reference}

1. Donina S, Strēle I, Proboka G, et al. Adapted ECHO-7 virus Rigvir immunotherapy (oncolytic virotherapy) prolongs survival in melanoma patients after surgical excision of the tumour in a retrospective study. Melanoma Res. 2015;25(5):421-426.
Oncolytic Virotherapy

\section{Publish your work in this journal}

Oncolytic Virotherapy is an international, peer-reviewed, open access online journal publishing original research, study protocols, reviews, editorials and commentaries on all aspects of oncolytic virology, namely the application of oncolytic viruses for the treatment of cancer. Specific topics in the journal include: Rationale and theoretical aspects of oncolytic virotherapy including in vitro, in vivo and mathematical

\section{Dovepress}

modeling; and practical application and problem solving in the clinic including identification of potential responders through biomarkers and genetic profiling. The manuscript management system is completely online and includes a very quick and fair peer-review system, which is all easy to use. Visit http://www.dovepress.com/

testimonials.php to read real quotes from published authors. 